\title{
ANALISIS DAN PERANCANGAN SISTEM E-MARKETING PADA PT NORDIC LIFT TRUCK
}

\author{
Haris Setia Budi; Wednes Pujiasmoro; Herjandi Wijaya; Yuliyanti \\ Computerized Accounting Department, School of Information Systems, Binus University \\ Jl. K.H. Syahdan No. 9, Palmerah, Jakarta Barat 11480 \\ harisbudi@binus.edu
}

\begin{abstract}
The purpose of research is to analyze the current marketing system at PT.Nordick Lift Truck in order to identify the existing problems faced by the company and to identify its weaknesses. Additionally, this research designs a web based Marketing system. The system has been designed to give facilitation for customer to get information abaut material of tutorial activity fast and efficient. The methodologies used are literature study, observation, interview, questionaire, analysis and design with 7-stages E-Marketing. It isconcluded that e-CRM system that has been designed supports information access easily and fast. The e-Marketing application consists of features such as Online Register, Contact us, Download, News, and Complaint. It is expected to help deliver and maintain customer satisfaction by building a close relationship to the customers.
\end{abstract}

Keywords: e-marketing, facilitation, information, customer satisfaction

\begin{abstract}
ABSTRAK
Tujuan penelitian adalah untuk menganalisis sistem pemasaran yang sedang berjalan di PT Nordic Lift Truck, guna mengidentifikasikan masalah yang sedang dihadapi perusahaan dan kelemahan yang ada. Selain itu, penelitian ini juga bertujuan untuk merancang suatu sistem pemasaran berbasis web. Pada sistem ini dirancang fasilitas yang dapat membantu kemudahan bagi client untuk mendapatkan informasi mengenai produk dan service dengan cepat dan efisien. Metodologi yang digunakan adalah studi pustaka, observasi, wawancara, kuesioner, analisis dan perancangan menggunakan tujuh tahapan e-marketing. Dapat disimpulkan bahwa sistem e-Marketing yang dirancang menyediakan fasilitas yang mendukung perolehan informasi secara mudah dan cepat. Aplikasi e-Marketing berbasiskan web ini berisi fitur-fitur seperti Register Online, Contact Us, Download, News, dan Complaint. Aplikasi ini diharapkan dapat membantu perusahaan dalam memberikan kepuasan bagi pelanggan dengan membangun dan mempertahankan hubungan yang lebih dekat dengan para pelanggannya.
\end{abstract}

Kata kunci: e-marketing, fasilitas, informasi, kepuasan pelanggan 


\section{PENDAHULUAN}

Dengan semakin pesatnya perkembangan teknologi informasi, banyak perubahan yang terjadi dalam cara hidup manusia. Hal ini menuntut manusia untuk senantiasa menyesuaikan pola hidupnya dengan perkembangan teknologi. Sama halnya dengan perusahaan-perusahaan, mulai dari perusahaan kecil hingga perusahaan berskala internasional saat ini bersaing untuk menguasai pasar dengan bantuan teknologi informasi. Kegunaan teknologi informasi adalah dapat meningkatkan kinerja organisasi, meningkatkan efektivitas dan efisiensi waktu, tenaga, biaya, meningkatkan produksi, promosi dan penjualan.

Berbagai macam produk teknologi yang dikembangkan dan diimplementasikan adalah teknologi internet. Pemasaran yang dilakukan dengan menggunakan teknologi internet dikenal dengan istilah e-marketing. E-marketing adalah proses pemasaran yang melibatkan teknologi secara online dengan website sebagai mediatornya.

Internet marketing cenderung mengacu kepada eksternal perspektif tentang bagaimana internet dapat digunakan bersama-sama dengan media tradisional untuk mendapatkan dan memberikan layanan kepada pelanggan (Chaffey, 2009, p417). Internet marketing juga disebut sebagai pemasaran web, pemasaran online atau pemasaran produk atau jasa melalui internet (Shukla, 2010, p9).

Konsep yang ditawarkan oleh e-marketing pada umumnya sama dengan konsep yang ditawarkan oleh bentuk pemasaran yang konvensional. Namun, dengan penggunaan website, perusahaan dapat lebih meningkatkan hubungannya dengan konsumen dan mempermudah perusahaan dalam memperluas pangsa pasarnya. Keuntungan bagi konsumen adalah dapat lebih mudah dalam mendapatkan informasi mengenai produk atau jasa yang ditawarkan oleh perusahaan dan dapat diakses kapan saja dan di mana saja selama ada koneksi internet.

Menurut Jamal (1996), keuntungan yang dapat diberikan dengan adanya penggunaan Emarketing ini bagi perusahaan yaitu mampu menjangkau berbagai konsumen dalam suatu lingkungan yang belum dipenuhi oleh pesaing, target adalah konsumen yang telah terbagi ke dalam kelompok dan mengembangkan dialog berkelanjutan. transaksi binis secara elektronik dan dengan biaya yang rendah, email dan data files dapat dipindahkan kepada konsumen yang terpilih atau semua konsumen dalam hitungan detik, jalur proses penjualan langsung dari produsen ke pengguna tanpa harus melewati jalur distribusi klasik, dapat menambahkan produk untuk dipasarkan secara cepat dan melakukan perubahan dalam rencana penjualan dengan sangat cepat, dapat melacak kegiatan penjualan yang sudah terjadi, langkah-langkahnya dan hasil yang didapat, dapat mengawasi pesaing, menciptakan dialog antara perusahaan dengan konsumen, dapat mendistribusikan program dan informasi tentang produk melalui email atau file transfer.

PT Nordic Lift-Truck merupakan perusahaan yang bergerak dibidang penjualan alat-alat berat seperti reachstaker dll. Kantor manajemen PT Nordic Lift-Truck terletak di Kompleks ruko Pulogadung Trade Centre. Kegiatan penjualan pada PT Nordic Lift-Trucks adalah proses pencatatan yang masih bersifat manual, sehingga perusahaan kesulitan memantau keluar masuk barang, serta posisi persediaan barang di gudang yang mengakibatkan seringnya terjadi kurang informasi antara jumlah spare part di gudang pada pencatatan dengan jumlah spare part secara fisik. Masalah lainnya yang dihadapi PT Nordic Lift-Trucks adalah ketika akan membuat laporan yang memadai dan reliable karena pembuatan laporan pada perusahaan ini dilakukan secara manual, sehingga dibutuhkan waktu yang lama dalam pembuatan laporan. Di samping itu, PT Nordic Lift-Trucks mengalami masalah dalam penjadwalan pengiriman barang kepada para pelanggan, misalnya dalam satu kali pengiriman ada kalanya barang dikirimkan kepada pelanggan yang berada di lokasi yang berjauhan sehingga 
proses pendistribusian menjadi tidak efektif dan efisien karena terlalu lama memakan waktu dan biaya untuk operasional perusahaan.

\section{METODE}

Metodologi yang digunakan dalam penulisan skripsi ini terdiri dari:

\section{Pengumpulan Data}

Data diperoleh melalui: (1) wawancara dengan bagian pemasaran untuk mendapatkan informasi tentang kondisi perusahaan secara keseluruhan dan proses pemasarannya; (2) survei atau pengamatan langsung ke dalam lingkungan perusahaan; (3) studi kepustakaan.

\section{Analisis dan Perancangan}

Analisis dan perancangan dilakukan berdasarkan tujuh tahapan internet marketing (Mohammed et al. (2006, p8-18), yaitu:

Tahap 1: membentuk peluang pasar (framming the market opportunity)

Tahap 2: memformulasikan strategi pemasaran (formulating the marketing strategy)

Tahap 3: mendesain pengalaman konsumen (designing the customer experience)

Tahap 4: merancang tampilan untuk konsumen (crafting the customer interface)

Tahap 5: merancang program pemasaran (designing the marketing program)

Tahap 6: pengadaan informasi konsumen melalui teknologi (leveraging customer information through technology)

Tahap 7: mengevaluasi program pemasaran (evaluating marketing program)

Analisis dilakukan dengan: (1) framing the market opportunity (Membentuk peluang pasar); (2) Formulating the market strategy (Menyusun strategi pemasaran); (3) Designing the customer Experience (Merancang pengalaman pelanggan); (4) survei atas sistem yang sedang berjalan; (5) Analisis terhadap temuan survey; (6) Identifikasi kebutuhan informasi.; (7) identifikasi kebutuhan perusahaan. Perancangan dilakukan dengan: (1) Crafting the customer interface (membangun hubungan antar muka dengan pelanggan); (2) designing the marketing program (Merancang program pemasaran); (3) Leveraging customer information trough technology (Meningkatkan informasi pelanggan melalui teknologi); (4) Evaluating the marketing program (Mengevaluasi program pemasaran). Pembuatan UML Diagram meliputi: rich picture, class diagram, use case diagram, overview activity diagram, navigation diagram, dan use case diagram.

\section{HASIL DAN PEMBAHASAN}

\section{Tahap 1: Membentuk Peluang Pasar (Framming The Market Opportunity)}

Menurut Mohammed et al. (2006, p36-68), tahap pertama ini meliputi analisis peluang pasar dan mengumpulkan data dari sistem yang online maupun offline untuk menciptakan penilaian peluang. Pada tahap ini terdapat lima langkah investigasi yang diikuti oleh suatu keputusan lanjut atau tidak lanjut (go / not go decision), yaitu:

Langkah 1: Investigate opportunity in an existing or new value system (menentukan peluang pada nilai sistem yang telah berjalan atau baru). 
Pada langkah ini dipergunakan untuk mengidentifikasi secara luas daerah mana yang akan dimasukin oleh perusahaan baru dan peluang-peluang apa saja yang memungkinkan perusahaan untuk masuk ke pasar, serta dengan adanya internet, apakah peluang yang dimiliki oleh perusahaan dapat lebih dikembangkan.

\section{Langkah 2: Identify unmet to unserved needs (mengidentifikasikan kebutuhan-kebutuhan yang belum terpenuhi).}

Langkah ini menggambarkan pencarian dari kebutuhan pelanggan yang belum terpenuhi. Proses memetakan kebutuhan pelanggan adalah suatu kerangka yang terorganisir untuk memudahkan para manajer dalam menemukan kebutuhan yang belum terpenuhi secara sistematis. Memetakan proses kebutuhan pelanggan akan memudahkan dalam menemukan ide-ide baru mengenai kebutuhan yang belum terpenuhi, dengan melakukan percakapan secara langsung dengan sejumlah pelanggan atau menganalisis proses bisnis yang berjalan di dalam perusahaan tersebut.

\section{Langkah 3: Determine target customer segment (Menentukan target segmentasi konsumen).}

Pengertian segmentasi adalah proses pengelompokan konsumen berdasarkan faktor-faktor tertentu. Pada langkah ini akan ditentukan segmentasi dari pengguna produk dari perusahaan. Adapun segmentasi pasar dapat dibedakan berdasarkan: (1) demografis - membagi pasar berdasarkan nilainilai demografis, seperti umur, jenis kelamin, pendidikan, etnis, pendapatan, status keluarga dan lain sebagainya; (2) geografis - membagi pasar ke dalam unit-unit geografis, seperti kota, negara, daerah, wilayah dan lain sebagainya; (3) firmografis - membagi pasar berdasarkan variabel spesifikasi perusahaan, seperti jumlah karyawan dan ukuran perusahaan; (4) tingkah laku - membagi pasar berdasarkan pada pengetahuan, sikap pemakaian atau tanggapan mereka terhadap suatu produk, seperti situasi yang menuntun kepada kebutuhan produk, pembelian atau kegunaan seperti yang bersifat rutin atau khusus; (5) psikografis - membagi pasar berdasarkan pada gaya hidup dan kepribadian; (6) kesempatan (tergantung situasi) - membagi pasar berdasarkan pada situasi yang mengarah pada kebutuhan suatu produk, membeli atau menggunakan, seperti kesempatan rutin dan kesempatan khusus; (7) keuntungan - membagi pasar berdasarkan pada keuntungan atau kualitas dari suatu produk, seperti kenyamanan, ekonomi dan kualitas.

\section{Langkah 4: Assess resource requirement to deliver the offering (Menilai kebutuhan sumber daya untuk memberikan penawaran)}

Pada langkah ini, perusahaan menganalisis kemampuan yang perlu dan sedang dimiliki perusahaan, baik dari sumber daya sendiri maupun dari partner yang potensial, sehingga dapat memberikan berbagai penawaran hingga ke pelanggan. Beberapa sumber daya tersebut adalah: (1) customer-facing resource, yang meliputi merek dagang, tenaga penjualan yang terlatih dengan baik dan berbagai saluran distribusi; (2) internal resource, sumber daya ini dihubungkan dengan operasioperasi internal perusahaan. contohnya: meliputi teknologi, pengembangan produk, skala ekonomi dan staff berpengalaman; (3) upstream resources, sumber daya ini dikaitkan dengan hubungan perusahaan dengan para pemasoknya, contohnya: hubungan kerjasama dengan berbagai pemasok dan tingkatan kerjasama operasional antara perusahaan dengan pemasoknya.

\section{Langkah 5: Assess competitive, technological and financial attractiveness of opportunity (Menilai kekuatan persaingan, teknologi dan keuangan perusahaan terhadap peluang)}

Pada langkah kelima ini, terdapat sembilan faktor dari empat area yang dapat digunakan untuk menentukan suatu karakter dan pentingnya sebuah kesempatan. Area-area tersebut adalah: (1) Competitive intensity - factor-faktor yang terkait pada keseluruhan intensitas kompetitif dapat dinyatakan dalam sebuah peta kompetitor yang meliputi: (a) jumlah dan indentitas dari masing-masing competitor; (b) kekuatan dan kelemahan pada penyampaian keuntungan. Untuk mengukur intensitas 
kompetitif, suatu perusahaan harus sungguh-sungguh mengindentifikasi pesaing yang akan mereka hadapi. Terdapat dua bentuk pesaing untuk sebuah proses bisnis: (c) direct competitor - pesaing dalam industri yang sama, yang menawarkan produk dan jasa yang sama; (d) indirect competitor - pesaing tidak langsung dapat dikategorikan menjadi dua kategori, yaitu: substitute producers, perusahaan lain yang menawarkan produk dan jasa yang berbeda namun memiliki fungsi yang sama dengan yang ditawarkan oleh perusahaan, dan adjacent competitors, pesaing yang tidak menawarkan produk yang langsung menjadi pengganti, namun memiliki potensi untuk menjadi substitute producers.

(2) Customers Dynamics - unsur-unsur yang membingkai keseluruhan dinamika pelanggan dari suatu pasar adalah: (a) tingkatan dari kebutuhan yang belum terpenuhi atau besarnya kesempatan yang tidak terbatas. Ini adalah jumlah pasarnya dengan sesuatu yang benar-benar baru; (b) tingkatan interaksi diantara segmen-segmen pelanggan utama. Hal ini adalah tingkatanaktivitas penguatan yang akan menghasilkan pembelian dan pemakaian yang lebih. Perusahaan yang memiliki dinamika anggota mempengaruhi anggota (viral dynamics), dapat dengan cepat menangkap banyak peluang; (c) tingkat pertumbuhan yang memungkinkan (likely rate of growth). Biasanya merujuk kepada presentasi dari pertumbuhan tahunan pelanggan. Pasar dengan tingkat pertumbuhan yang tinggi menghadirkan peluang yang signifikan bagi para pemainnya.

(3) Technology Vulnerability - meliputi: dampak dari penerapan kemampuan teknologi dan dampak dari teknologi baru pada suatu proporsi nilai. (4) Microeconomics - suatu kesempatan dalam ekonomi mikro meliputi: (a) ukuran atau isi dari suatu pasar (market size) yang merupakan nilai uang dari semua penjualan yang dihasilkan dalam pasar tertentu; (b) tingkat profitabilitas (level of profitability), yang merupakan margin keuntungan yang dapat direalisasikan dalam suatu pasar.

\section{Langkah 6: Conduct Go No-Go Decision (Membuat keputusan lanjut atau tidak lanjut)}

Pada segmen ini dilakukan penilaian terhadap peluang, sumber daya yang dimiliki perusahaan dan kebutuhan pelanggan yang belum terpenuhi untuk menilai besarnya dukungan terhadap pelaksanaan sistem pemasaran melalui internet.

\section{Tahap 2: Memformulasikan Strategi Pemasaran (Formulating Marketing Strategy)}

Strategi internet marketing berdasar pada perusahaan, unit bisnis dan keseluruhan dari strategi perusahaan. Tujuan strategi pemasaran, sumber daya dan ukuran kejadian harus disatukan dengan strategi unit bisnis. Pada akhirnya, keseluruhan pada strategi marketing meliputi aktifitas online dan offline. Tiga konsep dalam strategi pemasaran yaitu:

\section{Segmentasi (Segmentation)}

Proses pembagian atau pengelompokan pelanggan yang heterogen menjadi pelanggan yang homogeny (kesamaan dari sisi minat, daya beli, gaya hidup) dalam suatu sub unit tertentu yang membuat mereka menjadi bagian dari program pemasaran. Dengan mengacu pada matriks segmentasi Bricks and Mortar (Gambar 1), perusahaan dapat menentukan strategi segmentasi yang paling tepat dan yang paling sesuai untuk dijalankan.

Dimensi pertama dari matriks tersebut (Change in Segmentation Characteristics Due to Internet) menjelaskan mengenai karakteristik segmentasi pasar setelah perusahaan berpindah ke pemasaran melalui internet akan berubah atau tidak. Dimensi kedua (Change in Size of Market Segments) menjelaskan tentang ukuran segmentasi pasar setelah perusahaan beralih ke pemasaran melalui internet akan berubah atau tidak. 


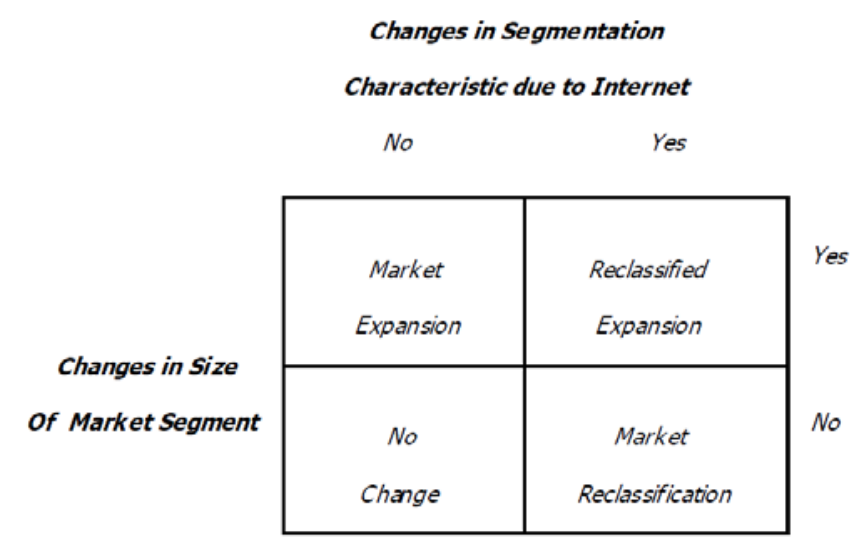

Gambar 1 Brick and Mortar Segmentation Scenarios (BAMS)

\section{Sasaran (Targetting)}

Proses penetapan segmen pasar (Gambar 2) yang paling menarik yang kemudian akan dijadikan target utama perusahaan dalam kegiatan akhir dari pemasaran yaitu penjualan, berdasarkan pada keuntungan, biaya pelayanan, mudah dijangkau dan potensi pertumbuhan.

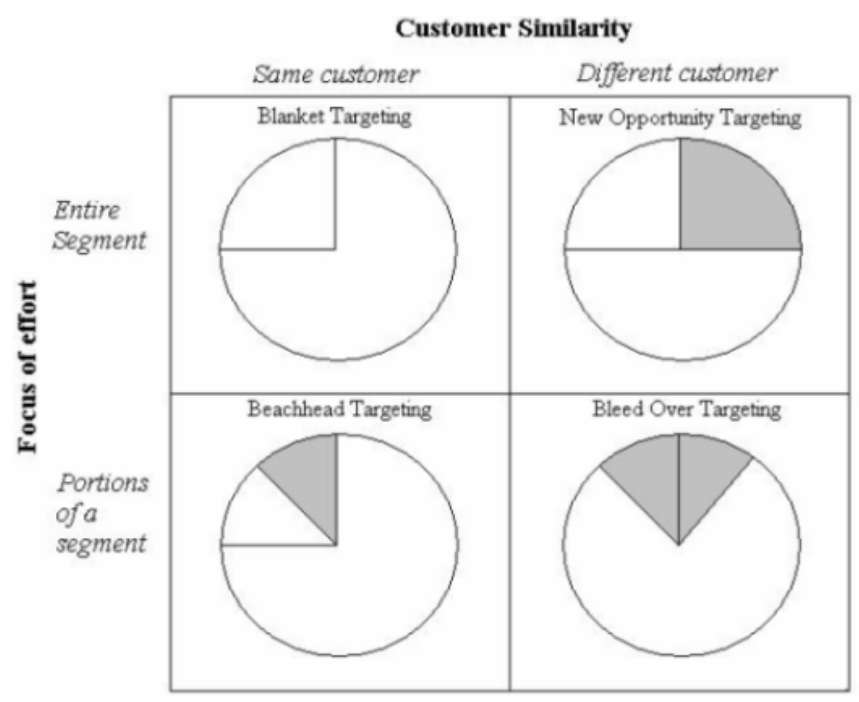

Gambar 2 Bricks and Mortar Targetting Scenarios.

Dari kedua dimensi di atas, diperoleh empat pilihan posisi, yaitu: (1) Blanket Targeting segmentasi online tidak menunjukkan adanya sesuatu yang baru, secara umum karakteristik pelanggan online sama dengan pelanggan offline. Namun segmen bertambah besar karena faktor seperti meningkatnya jangkauan geografis atau pelanggan offline perusahaan tersebut merupakan pengguna internet; (2) Beachhead Targeting - pada bagian ini ditemukan segmen online dari pelanggan lebih kecil dari offline. Hal ini terjadi karena hanya sebagian kecil pelanggan perusahaan yang menggunakan internet. Pelanggan-pelanggan ini mungkin penunjukkan peningkatan pilihan dengan menggunakan internet (untuk mengambil keuntungan dari yang ditawarkan online) tetapi biasanya masih memperlihatkan pilihan pembelian yang sama seperti pelanggan offline; (3) Bleed-Over Targeting - posisi di mana target segmentasi online merupakan sebagian dari offline ditambah dengan segmen baru pada saat online. Segmen baru tersebut, adakalanya merupakan konsumen yang selama 
ini terabaikan pada saat offline, namun pada saat ini menjadi target karena sistem online menawarkan sesuatu yang menarik bagi konsumen tersebut; (4) New Opportunity Targeting - posisi di mana target segmentasi online yang dilayani secara keseluruhan berbeda dari target segmentasi offline. Jika posisi ini terpilih sebagai suatu kondisi bagi perusahaan, biasanya perusahaan harus dapat menawarkan produk yang sama sekali berbeda dengan produk yang ditawarkan selama offline.

\section{Posisi (Positioning)}

Cara pandang perusahaan untuk mempengaruhi pelanggan tentang suatu produk yang unik dan mempunyai nilai pada target pasar sebagai langkah akhir dalam proses strategi pengambilan keputusan.

Blanket Positioning berfokus pada penawaran tambahan layanan yang bisa didapat dari internet seperti kenyamanan dan kemudahan akses. Di mana segmentasi targetnya tidak berubah, strategi akan banyak berasal dari strategi-strategi posisi offline yang telah ada. Beachhead Positioning berfokus pada blanket positioning, tetapi lebih berfokus pada komunitas konsumen yang lebih kecil. Posisi ini mengasumsikan bahwa segmen yang lebih kecil memberikan nilai yang lebih pada kemampuan internet seperti kenyamanan dan akses. Bleed-Over Positioning menyerupai penawaran offline, tetapi juga membuat penawaran online menarik bagi tipe konsumen baru. Strategi posisi tersebut akan mencoba untuk merujuk ke segmen-segmen yang berbeda dari sebelumnya. New Opportunity Positioning ditunjukkan pada segmen konsumen baru.

\section{Tahap 3: Mendesain Pengalaman Konsumen (Designing Customer Experience)}

Perusahaan harus mengerti tipe pengalaman pelanggan yang perlu diberikan untuk memenuhi peluang pasar. Pengalamannya harus berhubungan dengan posisi perusahaan dan strategi pemasaran. Rancangan dari pengalaman pelanggan merupakan penghubung antara strategi pemasaran tingkat tinggi dengan taktik program pemasaran. Tiga tahapan hierarki dari pengalaman pelanggan adalah: (1) experience functionality - bagaimana perusahaan memberikan produk yang sesuai kepada pelanggan sesuai dengan keinginan pasar dan sesuai dengan periode waktu yang ada; (2) experience intimacy suatu usaha perusahaan mengajak pelanggan agar pelanggan merasa lebih dekat dengan perusahaan sehingga mereka merasa dimengerti; (3) experience evangelism - pelanggan yang digambarkan sebagai individual experience, mengintegrasikan brand perusahaan ke dalam kehidupannya. pada tahap ini pelanggan menjadi seorang evangelist yaitu seorang pelanggan yang menyebarluaskan suatu produk atau brand. mereka mendapatkan suatu pengalaman dan mendapatkan suatu nilai kepuasaan yang besar terhadap produk sehingga tidak dapat menunggu untuk dapat membagikan cerita tersebut kepada teman dan rekan kerja mereka.

\section{Tahap 4: merancang tampilan untuk konsumen (crafting the customer interface)}

Perancangan customer interface mencakup beberapa elemen, yaitu: (1) Context - Menekankan pada bagaimana sebuah website dirancang baik secara estetik maupun fungsional. Secara estetik berarti menggambarkan karakteristik visual dari website seperti warna, grafik, foto, pemakaian huruf; (2) Content - semua subjek digital yang ada di dalam sebuah situs web. Content juga mencakup medium subjek digital seperti teks, video, audio dan gambar. Sebagaimana pesan yang disampaikan oleh subjek digital juga mencakup produk, jasa dan informasi yang ditawarkan. Jika context lebih berfokus pada bagaimana sebuah situs dirancang, content lebih berfokus pada apa yang disampaikan; (3) Community - Merupakan sebuah set hubungan yang dibangun berdasarkan minat-minat yang dibagikan. Komunitas memiliki beberapa kegunaan, yaitu dapat membuat isi atau layanan-layanan menarik konsumen kepada sebuah website, dapat juga disediakan sebagai arti untuk membangun hubungan yang lebih dekat antara konsumen dengan perusahaan dan antara konsumen dengan konsumen; (4) Customization - didefinisikan sebagai kemampuan situs untuk memodifikasi dirinya 
atau dapat dimodifikasi oleh setiap pengguna; (5) Connection - didefinisikan sebagai jaringan link antara situs kita dengan situs-situs, dengan lain link yang diklik akan membawa pemakai keluar dari situs kita dan masuk ke situs orang lain; (6) Commerce - Didefinisikan sebagai kapasitas transaksi dari sebuah situs, penjualan produk atau jasa pada sebuah situs, bersamaan dengan adanya keranjang belanja, pengiriman dan pilihan pembayaran, check-out dan konfirmasi pemesanan.

\section{Tahap 5: Merancang Program Pemasaran (Designing Marketing Program)}

Tahap kelima merancang kombinasi dari tindakan pemasaran (yang disebut lever) untuk memindahkan pelanggan target mulai dari awareness (kesadaran), exploration, commitment, dan dissolution (pemutusan hubungan). Pelanggan tidak perlu melalui keempat tahap ini. Mereka bisa dari tahap kesadaran langsung ke tahap komitmen atau dissolution, atau dari tahap eksplorasi langsung ke tahap dissolution tanpa melalui tahap komitmen.

Kerangka kerja yang digunakan untuk menyelesaikan tugas ini adalah Marketplace Matrix. Pemasaran internet memiliki enam kelas lever yang terdiri dari: product, pricing, communication, community, distribution dan branding.

\section{Tahap 6: Pengadaan Informasi Konsumen Melalui Teknologi (Leveraging Customer Information Through Technology)}

Dalam tahap ini, perusahaan dapat menggunakan bantuan teknologi untuk mendapatkan, mengorganisasikan, menganalisis dan memanfaatkan informasi mengenai pelanggan dalam menentukan riset pasar, basis data pemasaran dan Customer Relationship Management (CRM). Perusahaan harus dapat bertindak berdasarkan 3 keputusan kunci berikut ini: (1) Marketing research, yaitu penelitian yang digunakan perusahaan untuk mengetahui kebutuhan konsumen dan memenuhi keinginan konsumen tersebut; (2) Database marketing, biasanya berisi data-data mengenai perilaku pembelian konsumen dan informasi ini akan digunakan untuk menentukan respon konsumen terhadap tawaran yang akan diberikan. Keuntungan yang didapat dari database marketing adalah adanya kemungkinan untuk dilakukan pendekatan secara individual dengan konsumen, personalisasi dan pengeluaran yang efisien; (3) Customer relationship management, ini adalah salah satu cara untuk mempertahankan konsumen setelah perusahaan mendapatkan konsumen, di mana perusahaan lebih fokus pada masing-masing kebutuhan tiap konsumen.

\section{Tahap 7: Mengevaluasi Program Pemasaran (Evaluating Marketing Program)}

Pada tahap akhir ini berguna dalam menilai dan mengevaluasi program pemasaran internet secara keseluruhan. Evaluasi tersebut dilakukan dengan cara pengukuran customer based, financial dan implementasi program serta halaman situs. Perusahaan juga meninjau kembali program pemasaran yang telah disusun melalui proses pengukuran dengan menggunakan matriks yang tujuannya untuk menilai tingkat keberhasilannya. Menurut David (2009, p145) Model Lima Kekuatan Porter (porter's Five-Forces Model) tentang analisis kompetitif adalah pendekatan yang digunakan secara luas untuk mengembangan strategi dalam banyak industri. Menurut Porter, hakikat persaingan suatu industri dapat dilihat sebagai kombinasi atas lima kekuatan, yaitu persaingan antar perusahaan sejenis, kemungkinan masuknya pesaing baru, potensi pengembangan produk substitusi, kekuatan tawar menawar penjual/pemasok dan kekuatan pembeli/konsumen.

\section{Merancang Customer Interface}

Dalam context diatur peletakan menu dan tata warna yang menarik bagi customer. Tomboltombol navigasi dibuat secara terstruktur sesuai dengan isi pokok dari situs Web. Website memberikan kemudahan kepada user melalui fasilitas penjumlahan otomatis barang yang dipilih untuk 
mempermudah pelanggan menghitung kuota pembelanjaan produk yang diberikan oleh perusahaan pelanggan atau dalam rangka penghitungan dana tersedia. Estetika dari website adalah dari warna yang didominasi warna putih biru berwarna dasar putih yang memberikan kesan fokus, lebih bersih pada gambar, dan isi informasi yang ditampilkan oleh website.

Website juga menampilkan foto-foto dari produk dan sparepart yang ditawarkan lengkap dengan harga satuannya. Hal ini akan sangat membantu pelanggan dalam menentukan pembelian atau sekedar untuk melakukan perbandingan harga dengan harga spare part yang ada di pasaran. Foto yang ditampilkan disediakan dengan ukuran file yang tidak terlalu besar. Hal ini akan mempercepat proses loading foto saat pelanggan membuka website sehingga proses loading foto tidak memakan waktu yang lama, Font pada website yang digunakan adalah kombinasi dari huruf Calibri, dan Calibri (Body). Jenis font ini dipilih karena tampilannya lebih enak dibaca melalui suatu website dan berkesan elegant serta terlihat lebih jelas dan lebih besar dibandingkan dengan font Times New Roman yang biasanya dipergunakan pada website. Informasi yang ditampilkan secara lengkap dengan penyajian tulisan yang singkat dan padat dengan kata-kata yang tidak berbelit-belit tetapi jelas dibaca customer. Hal ini dilakukan dalam rangka memberikan informasi yang lengkap, cepat, padat, dan singkat tetapi mudah dimengerti oleh user. Berikut adalah sebagian tampilan layar dari keseluruhan yang dirancang (Gambar 3 - 7). Gambar 8 - 11 menampilkan beberapa diagram yang dibuat.

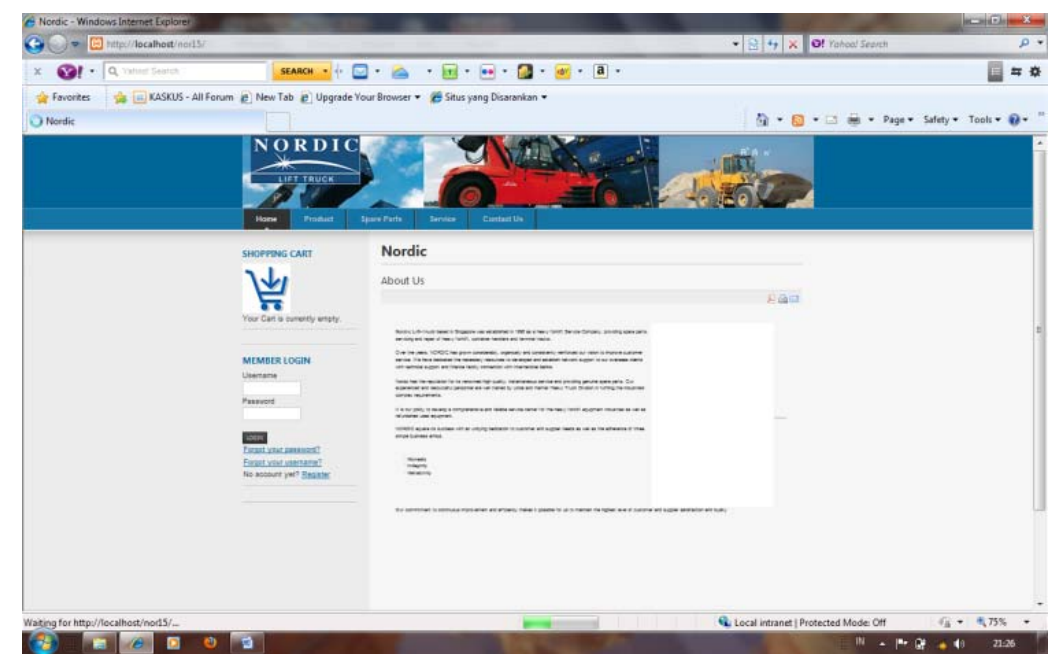

Gambar 3Tampilan Layar Utama Guest.

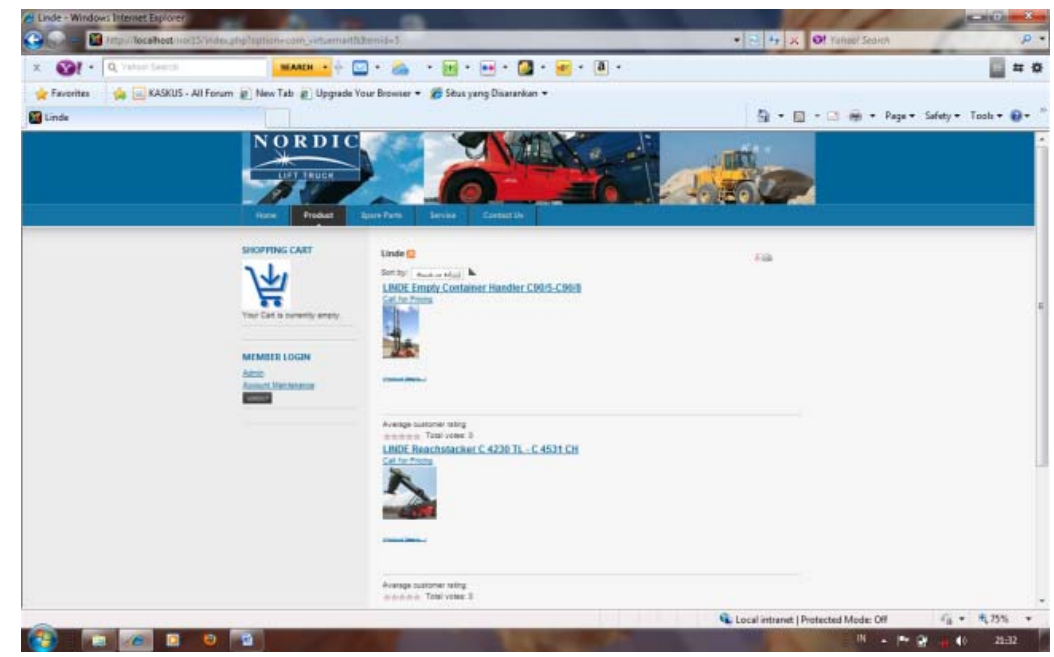

Gambar 4 Tampilan Layar Produk Guest. 


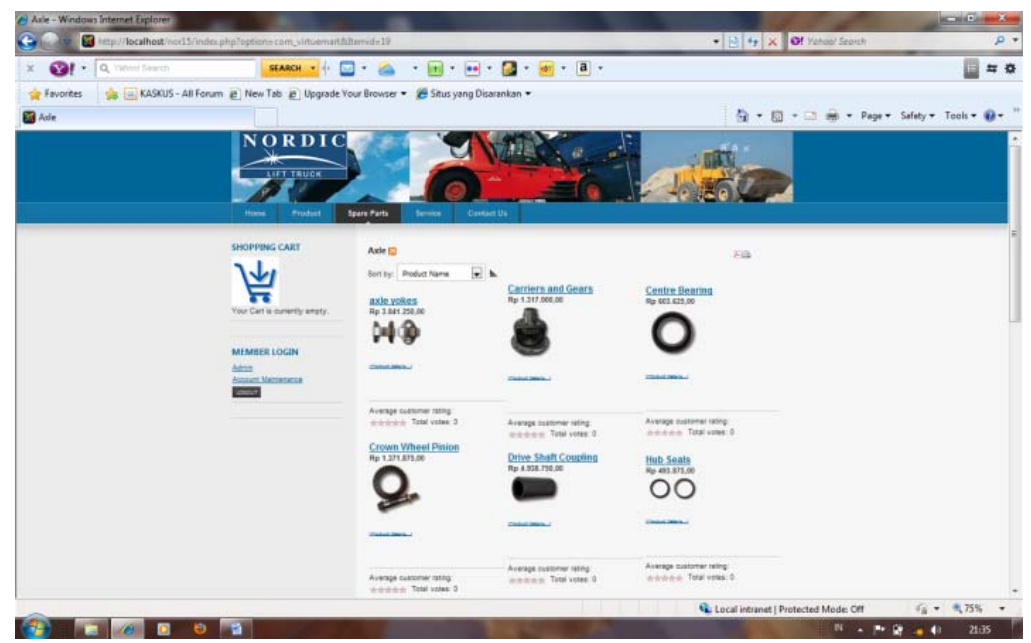

Gambar 5 Tampilan Layar Spare Part Guest

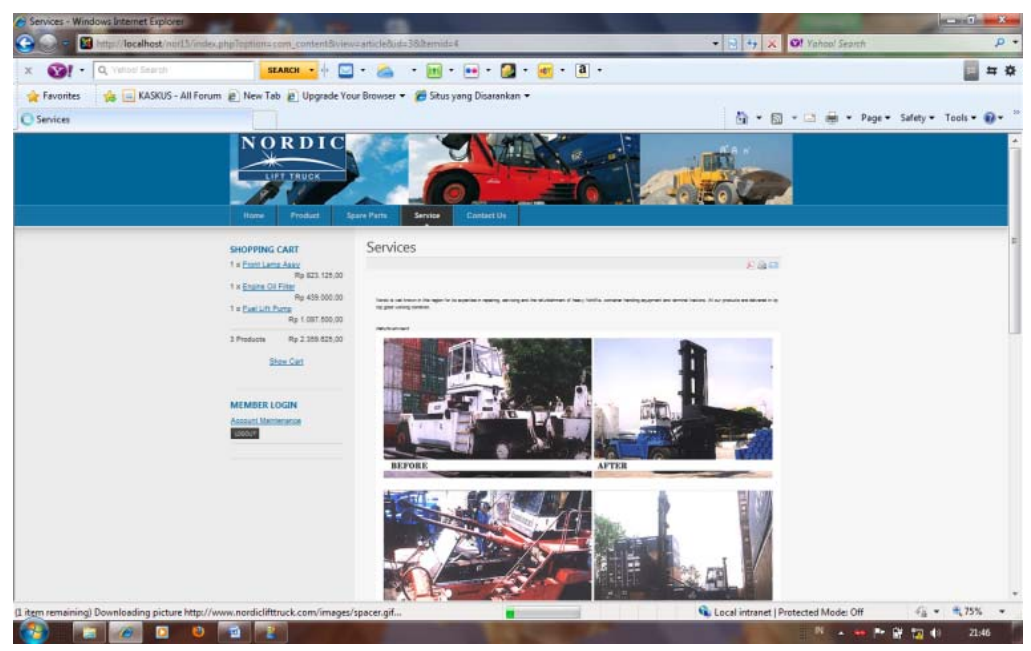

Gambar 6 Tampilan Layar Services Guest.

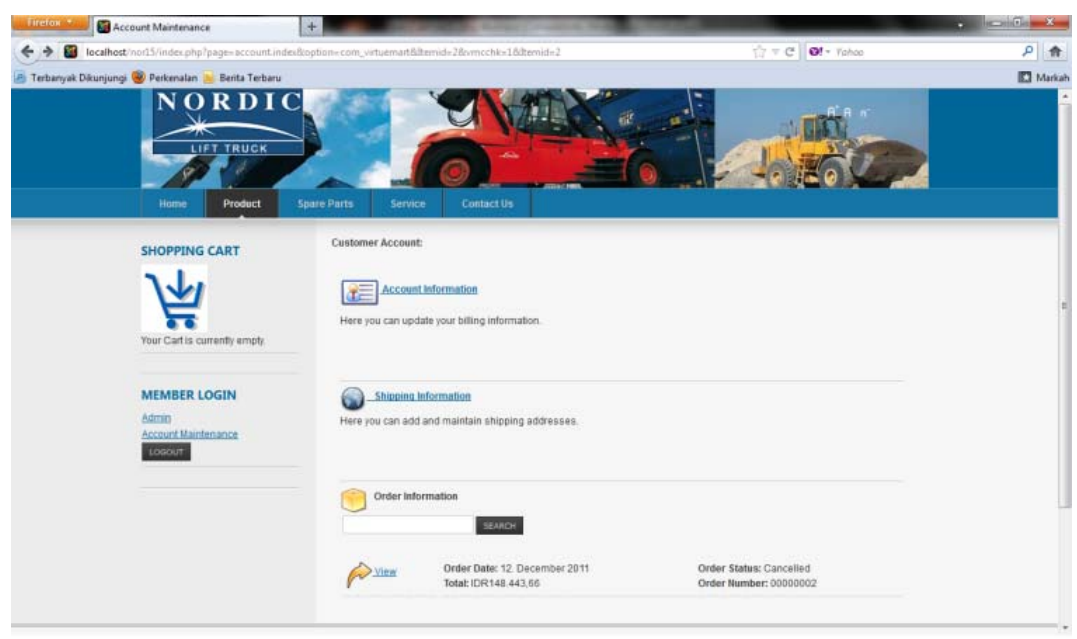

Gambar 7 Tampilan layar Home Admin. 


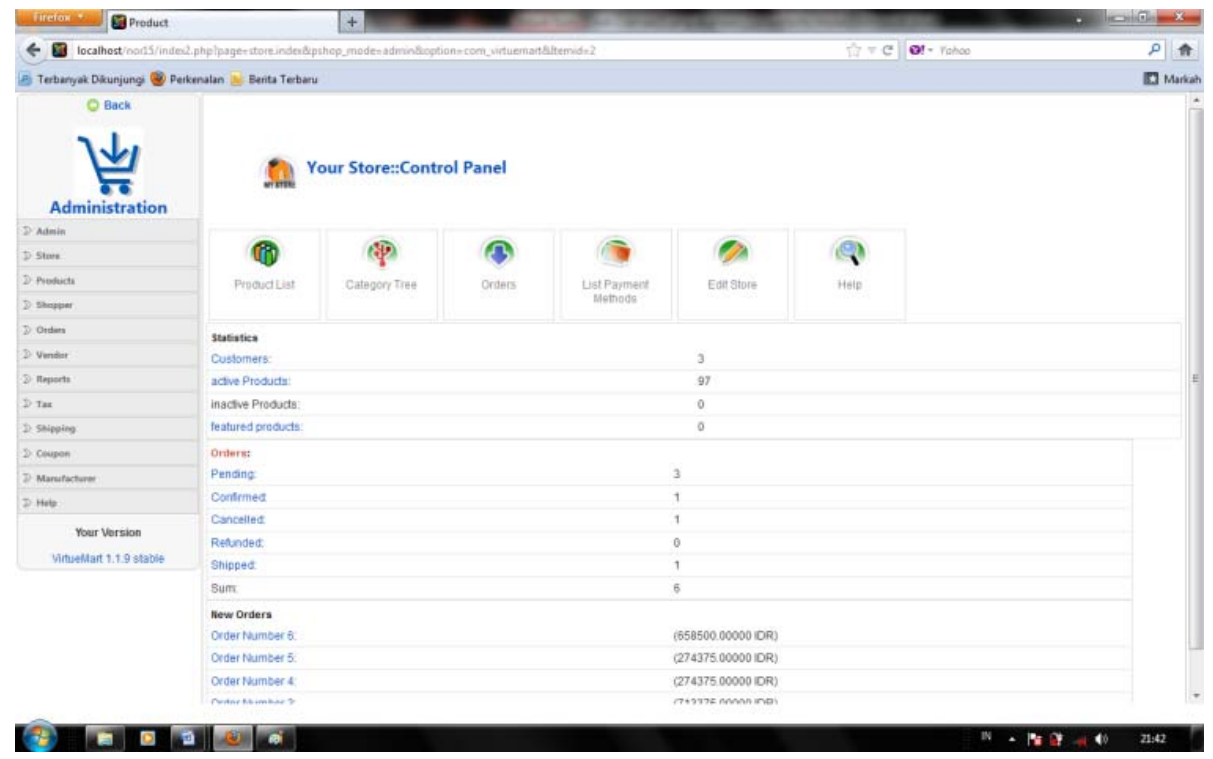

Gambar 8 Tampilan layar Control Panel Admin

\section{Evaluasi Program Pemasaran}

Untuk melakukan penilaian terhadap kinerja E-Marketing yang akan digunakan beberapa metrics atau indikator yang menggambarkan seberapa sukses implementasi dari $e$-marketing pada PT Nordic Lift Truck. Perusahaan juga meninjau kembali program pemasaran yang telah disusun melalui proses pengukuran dengan menggunakan matriks yang tujuannya untuk menilai tingkat keberhasilannya.

\section{Financial Metrics}

Untuk indikator finansial PT Nordic Lift Truck, dapat diukur dari 3 dimensi, yaitu sales atau jumlah penjualan dalam waktu kurun tertentu, revenue atau jumlah pendapatan yang didapatkan, dan marketing spend, yaitu perbandingan antara biaya dan keuntungan dalam proyek e-marketing ini.

\section{Sales}

Untuk dimensi ini dapat dilakukan pengukuran pada jumlah penjualan dalam kurun waktu tertentu, misalnya penjualan per bulan atau per tahun. Dari sini, peningkatan penjualan PT Nordic Lift Truck yang terjadi setelah dilakukan implementasi -marketing dapat dijadikan salah satu tolak ukur keberhasilan dalam implementasi strategi marketing yang baru ini.

\section{Revenue}

Sama seperti penjualan, seiring dengan peningkatan penjualan, maka akan terjadi peningkatan pada pendapatan yang didapatkan Nordic Lift Truck. Hal ini juga dapat dijadikan salah satu tolok ukur untuk melihat seberapa berhasil implementasi e-marketing yang baru.

\section{Marketing Spend}

Dimensi marketing spend dilakukan dengan cara evaluasi biaya yang dikeluarkan PT Nordic Lift Truck dalam melakukan implementasi proyek e-marketing ini dengan peningkatan keuntungan yang didapatkan kedepan. 


\section{Implementation Metrics}

Kedepan, keberhasilan implementasi website PT Nordic Lift Truck dapat diukur berdasarkan hits jumlah user yang mengunjungi website ini. Dengan menggunakan beberapa software untuk statistik kunjungan sebuah website yang banyak tersebar dan dapat diunduh secara gratis, maka akan memudahkan untuk melihat laporan kunjungan website Nordic Lift Truck dalam waktu tertentu. Dari sini, nantinya dapat digunakan untuk mengambil keputusan sehubungan dengan inovasi yang mungkin diinginkan untuk melakukan rating dari website tersebut.

\section{PENUTUP}

Berdasarkan hasil analisis dan perancangan sistem e-marketing yang telah dilakukan pada PT Nordic Lift-Truck, maka diperoleh kesimpulan bahwa salah satu usaha untuk meningkatkan pangsa pasar PT Nordic Lift-Truck adalah dengan menyediakan sebuah fitur pemesanan online yang dapat memudahkan pelanggan dalam melakukan pemesana barang yang dapat diakses selama 24 jam melalui jaringan internet dan dapat diproses saat itu ataupun keesokan harinya oleh pihak admin perusahaan, sehingga dapat meningkatkan keunggulan perusahaan.

Dengan adanya pemasaran dan pemesana secara online dapat mendukung perusahaan untuk menyediakan informasi bagi pelanggan yang up-to-date, lebih lengkap, efisien, dan dapat memberikan kenyamanan dan kemudahan bagi pelanggan. Kemudahan mendapatkan informasi bagi calon pelanggan atau pelanggan menjadi hal yang penting di tengah persaingan bisnis yang sangat tinggi .

\section{DAFTAR PUSTAKA}

Chaffey, Dave. (2009). E-Business and E-Commerce Management ( $4^{\text {th }}$ edition). New Jersey: Prentice Hall.

David, Fred R. (2009). Manajemen Strategis Konsep (edisi 12). Jakarta: Salemba Empat.

Shukla, Timira. (2010). Factors affecting 'internet marketing' campaigns with reference to viral and marketing. IUP Journal of Management Research, 9 (1): 26. 


\section{APPENDIX}

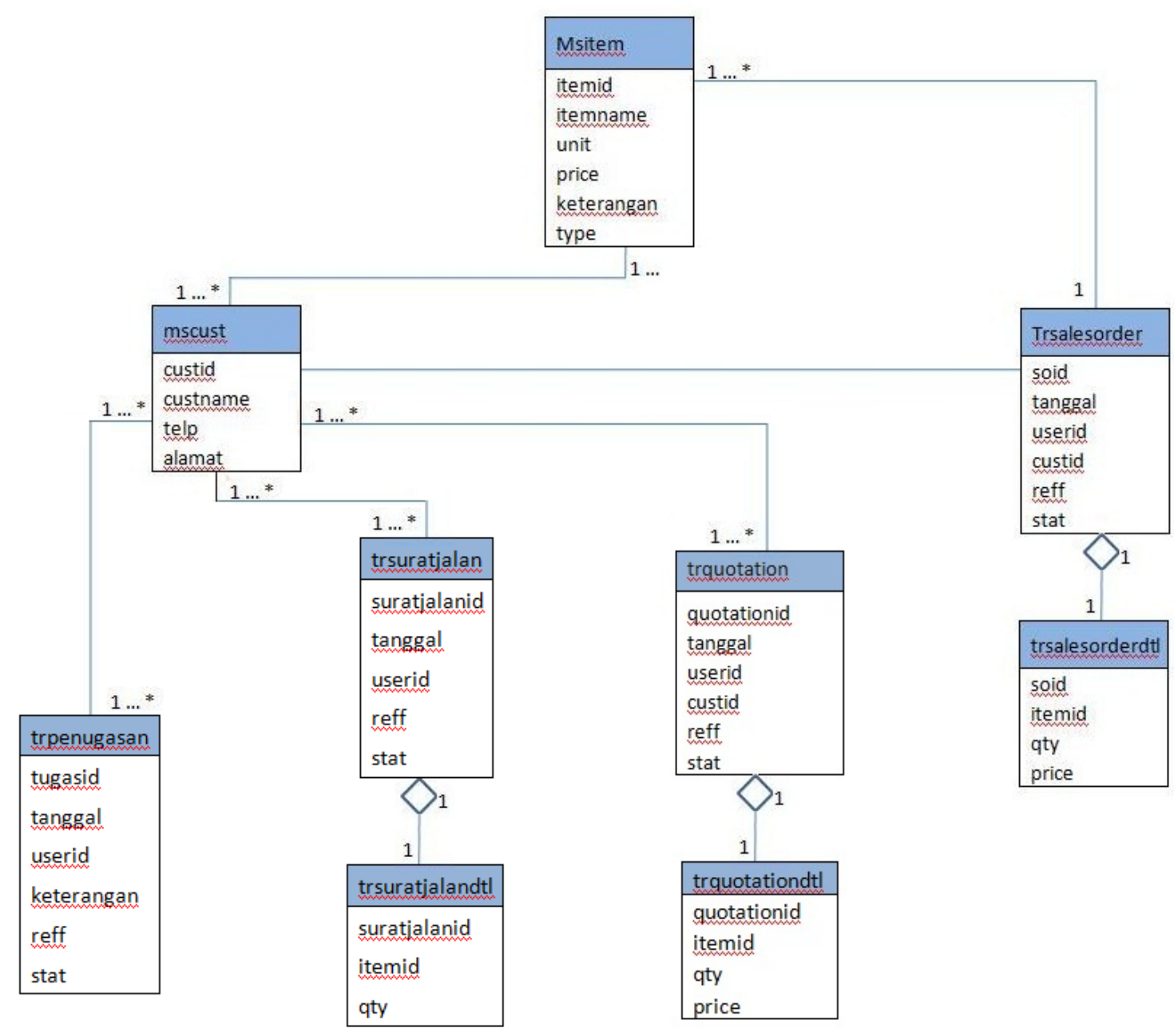

Gambar 9 Class Diagram yang diusulkan 


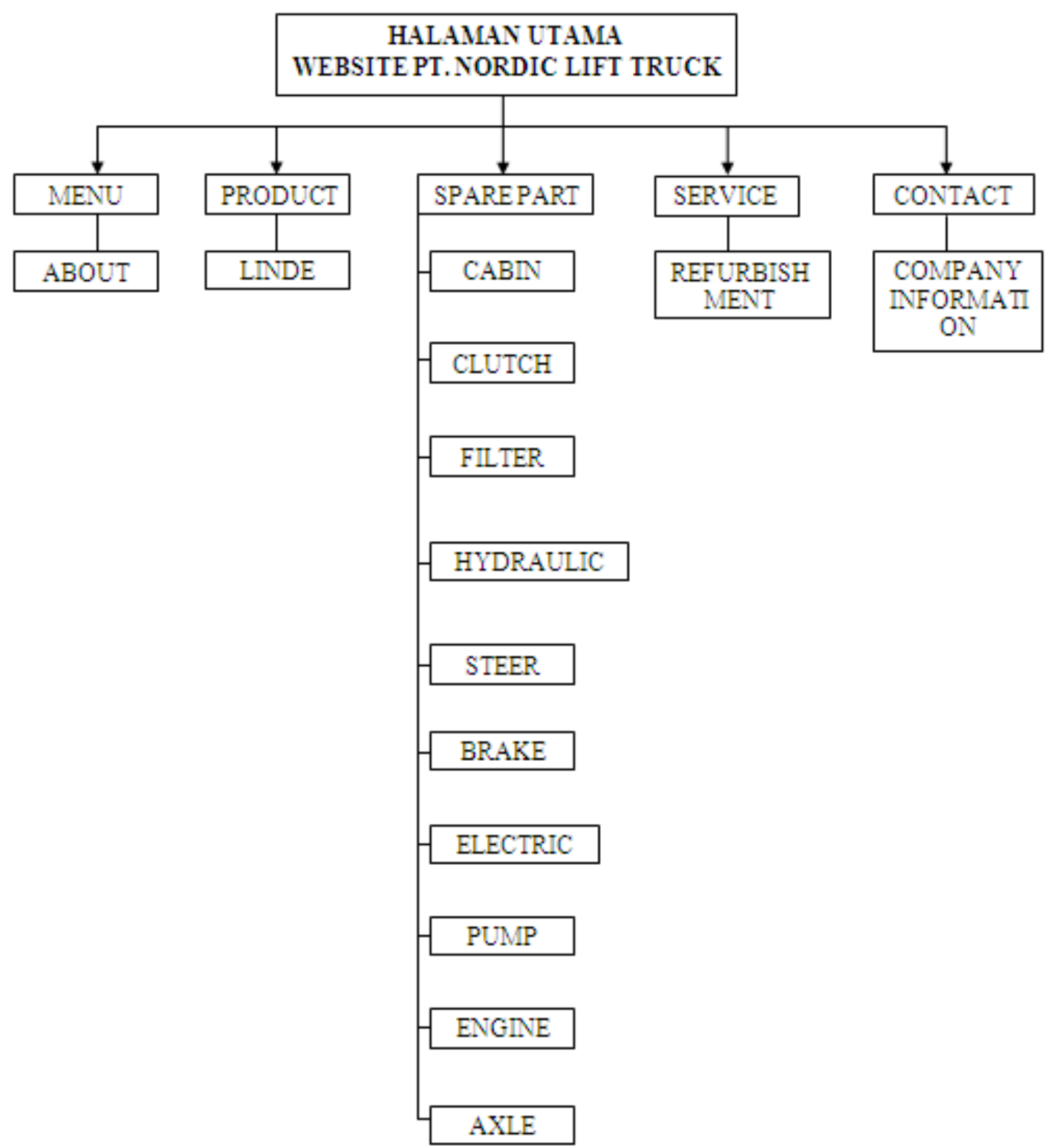

Gambar 10 Site Map 


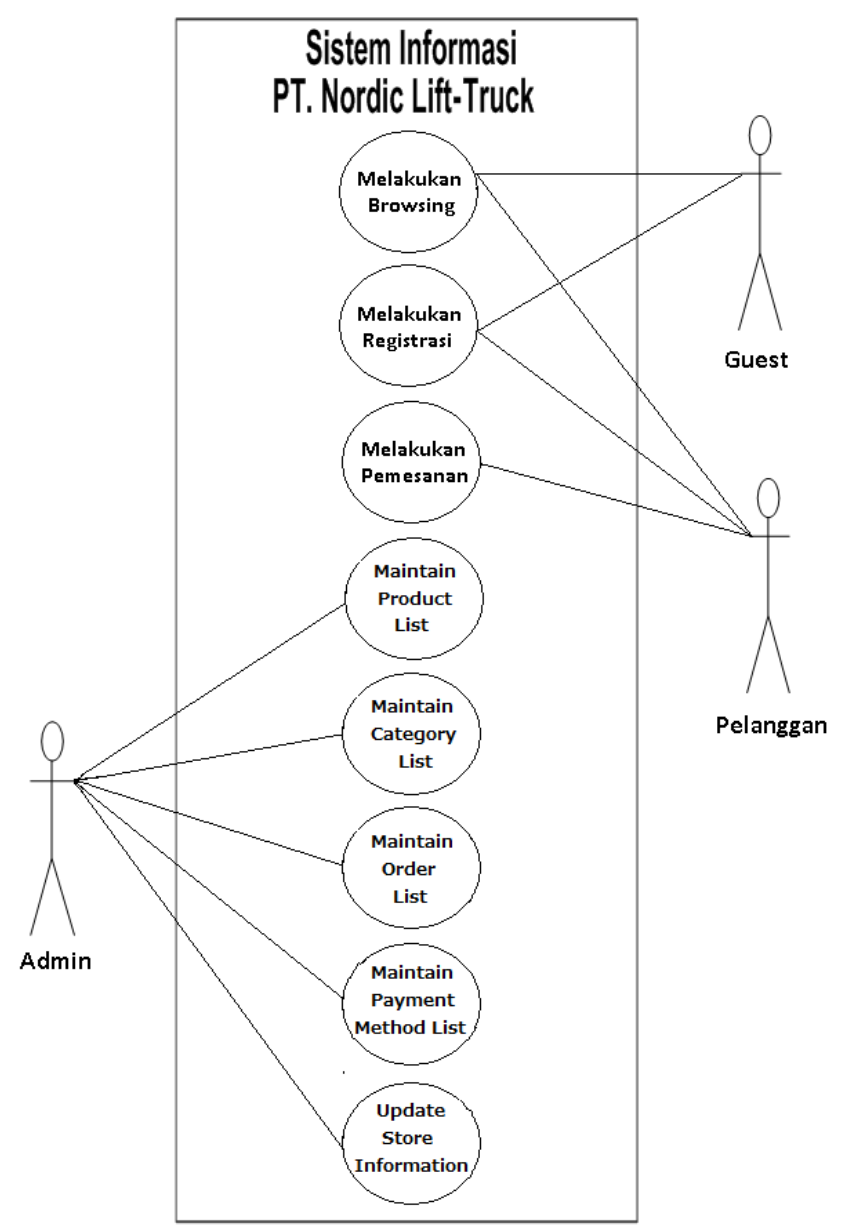

Gambar 11 Use Case yang diusulkan

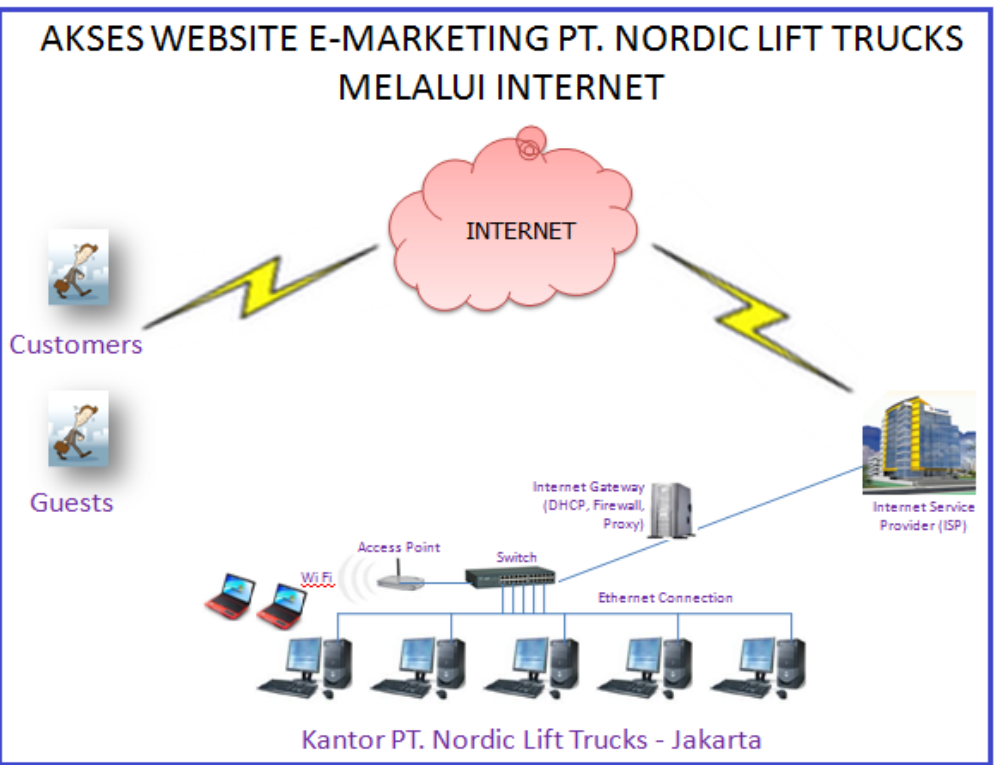

Gambar 12 Diagram Area Network PT Nordic Lift Truck 